\title{
Psychological Contract Breach and Work Performance in the Public Sector in Ghana
}

\author{
*Christine Ampofo-Ansah ${ }^{1}$, Joseph Ampofo Ansah ${ }^{2}$ \\ 1 Accra Technical University, Accra, Ghana, Department of Secretaryship and Management Studies \\ ${ }^{2}$ Land Commission, Land Registration Division, Ghana \\ *christine_ansab@yahoo.com
}

\begin{abstract}
Work in organizations entails an exchange relationship between employees and organization. Apart from the written employment contract, there still exists a set of mutual expectations from the two parties (employer and employee) which remain unwritten and unvoiced and yet drives the behavior of both workers and organizations alike, and this is what is referred to as the psychological contract. Psychological contract refers to the employees' subjective interpretations and evaluations of their deal with the organization. The aim of this study is to explore the impact of breaches or violations in the psychological contract on the performance of employees. It aims to present two concurrent hypotheses, based on theoretical interaction effects of social exchanges (conceptualized as social exchange relationships, fairness, and job security).Data were collected from a sample of 150 employees from both Public and Private Banks in Ghana. Regression analysis was used to explore the moderating effects of social exchanges on the relationships between psychological contract breach and work performance (operationalized as inrole behaviors and organizational citizenship behaviors).It was found that the negative relationship between psychological contract breach and work performance was moderated by social exchanges, such that the relationship was stronger for employees with high social exchange relationship, perceived organizational support, and job security which means that psychological contract breach will negatively affect employees with higher expectations in social exchanges.
\end{abstract}

Keywords: Breach of contract; Social interaction; Psychological contracts; Job satisfaction

\section{Introduction}

Psychological contract breach is defined as the cognition that the organization has failed to meet one or more obligations within the scope of the psychological contract whereas the employee has fulfilled his or her obligations (Morrison \& Robinson, 2009). Previous research has supported the relationship between psychological contract breach and various performance dimensions as purported by. Turnley et al., 2011). The processes through which contract breach leads to work performance has received less empirical attention. Since psychological contract researchers use social exchanges between the employer and the employee as an explanatory framework, in the current study we examine breach processes from this perspective.

This study contributes to existing knowledge on the consequences of psychological contracts and their relationship with performance (e.g. Turnley et al., 2011) by examining theory-based and heretofore empirically unexamined interactions between contract breach and these forms of social exchange. Moreover, the paper contributes to existing research by focusing on social exchanges as moderators in the relationships with work behaviors, instead of investigating social exchanges as outcomes or predictors of psychological contract breach (e.g. Dulac et al., 2008; Tekleab et al., 2009). However the paper seeks to: 
- $\quad$ study the psychological contract that exists between public sector professionals and public institutions.

- $\quad$ find out if contract breach of the terms of the psychological contract evokes a feeling which is strong enough to make the employee leave the organization?

Psychological contract breach are positively related to actual turnover (Guzzo et al, 2009). But since the actual exit from the organization depends on other factors like availability of attractive employment alternatives at the point of time of Psychological contract breach or the period immediately following it, we propose to measure the 'Intention to quit' rather than the 'actual exit' and study its relationship with Psychological Contract breach

- Hypothesis H0: There is no significant relationship between Psychological contract breach and employees performance.

- Hypothesis H1: There is a significant relationship between Psychological contract breach and employees performance.

\section{Methodology}

The study adopted descriptive research method. The Sampling Technique used was Non- Probability, which is purposive sampling. Data was collected from both public banks and private banks within the Greater Accra Region of Ghana. In all 150 respondents were randomly selected using the quota sampling method. The sample size was considered because it gives a good representation to the study.

Study participants were in professional positions (administrative and operations), with more than 75 percent of them in non-supervisory jobs, including administrative assistants, cashiers, accountants, and relationship officers. Based on the $\mathrm{O}^{*} \mathrm{NET}$ system of job classification (Mumford and

Peterson, 2009), employees were involved in tasks with moderate to high levels of autonomy and interdependence.

Data was collected using self-report questionnaires, based on 150 employees who completed the survey. Out of the 150 participants, 78 percent were males, 72 percent had at least some college education, 75 percent were 30 years or older, 80 percent had worked for the organization for more than three years, and 68 percent had been on the current position for more than a year. The study was interested to measure both work performance and discretionary behaviors in the form of citizenship. Since psychological contract breach refers to organizational failure to meet its obligations, this study anticipated that, the reactions to breach will predict organization-directed citizenship behaviors (Lavelle et al., 2011).

The paper used previously published scales to collect data relevant for the study. All measures were assessed using a five-point Likert-type scale (1 $1 / 4$ strongly disagree; $21 / 4$ disagree; $31 / 4$

neither agree nor disagree; $41 / 4$ agree; and $51 / 4$ strongly agree).

\section{Psychological contract breach}

In previous research, two different measures have been developed to investigate psychological contract breach (Zhao et al., 2007). On the one hand, contentspecific measures include items referring to specific employer promises (e.g. pay), and measure employees' perceptions of breach of these specific promises. On the other hand, global scales have been developed that measure global assessments of perceptions of breach of promises (Robinson and Morrison, 2010).

\section{Results and Discussions}

Table 1 below shows the extent of expectations of employees in respect of 7 employer obligations which are part of their Psychological contract. The maximum value is for 'Obligation to provide job security' and the minimum value is for 'Obligation to provide promotion'.

\section{Table 1}

Extent of expectations of employees

\begin{tabular}{|c|c|c|c|c|}
\hline & $\begin{array}{l}\mathrm{N} \\
\text { Valid }\end{array}$ & Missing & Mean & Std Dev \\
\hline $\begin{array}{l}\text { Obligation to } \\
\text { provide } \\
\text { Promotion }\end{array}$ & 150 & 20 & 2.623 & 3.6 \\
\hline $\begin{array}{l}\text { Obligation to } \\
\text { provide High }\end{array}$ & 150 & 40 & 2.498 & 3.6 \\
\hline $\begin{array}{l}\text { Obligation to } \\
\text { provide Pay }\end{array}$ & 150 & 40 & 2.456 & 3.6 \\
\hline $\begin{array}{l}\text { based on } \\
\text { Obligation to } \\
\text { provide }\end{array}$ & 150 & 40 & 2.412 & 4.5 \\
\hline $\begin{array}{l}\text { Obligation to } \\
\text { provide Job } \\
\text { security }\end{array}$ & 150 & 40 & 2.465 & 4.6 \\
\hline $\begin{array}{l}\text { Obligation to } \\
\text { provide } \\
\text { Career } \\
\text { Development }\end{array}$ & 150 & 40 & 2.478 & 4.6 \\
\hline
\end{tabular}




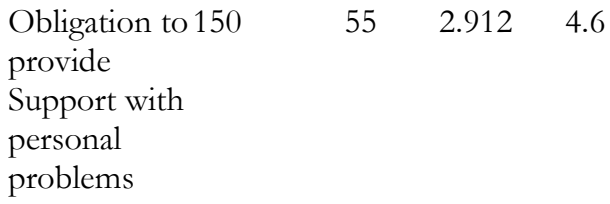

Table 2 below shows the expectation attached to the employer obligations by the bank employees.

Question I accounted for a mean of 2.623 of the total variance on expectation attached to Promotion as an employer obligations by the bank employees.

Question II accounted for a mean of 2.498 of the total variance on expectation attached to high pay as an employer obligation by the bank employees.

Question III accounted for a mean of 2.456 of the total variance on expectation attached to training as an employer obligation by the bank employees.

In Question IV had a mean of 2.412 of the total variance on expectation attached to job security as an employer obligation by the bank employees.

Question $\mathrm{V}$ accounted for a mean of 24 of the total variance on expectation attached to career development as an employer obligation by bank employees.

Question VI calculated a mean of 24 of the total variance on expectation attached to Personnel support as an employer obligation by the bank employees.

The maximum value is for 'Career Development' closely followed by 'High pay' and 'Job security'. The minimum value is for 'Support with personal problems'.

Table 2

Importance attached to employer obligations

\begin{tabular}{lllll}
\hline & $\begin{array}{l}\text { N } \\
\text { Valid }\end{array}$ & $\begin{array}{l}\text { Miss } \\
\text { ing }\end{array}$ & Mean & Std Dev \\
& 150 & 0 & 26 & 0.6 \\
\hline $\begin{array}{l}\text { How important } \\
\text { is Promotion }\end{array}$ & 150 & 0 & 24 & 0.6 \\
$\begin{array}{l}\text { How important } \\
\text { is High Pay }\end{array}$ & 150 & 0 & 24 & 0.6 \\
$\begin{array}{l}\text { How important } \\
\text { is Pay based } \\
\text { onPerformance }\end{array}$ & 150 & 0 & 24 & 0.5 \\
$\begin{array}{l}\text { How important } \\
\text { is Training }\end{array}$ & 150 & 0 & 24 & 0.6 \\
$\begin{array}{l}\text { How important } \\
\text { Is Job security }\end{array}$ & 150 & 0 & 24 & 0.6 \\
$\begin{array}{l}\text { How important } \\
\text { is Career } \\
\text { Development }\end{array}$ & & & & \\
& & & &
\end{tabular}

$\begin{array}{lllll}\text { How important } & 150 & 0 & 29 & 0.6 \\ \text { is support } & & & & \\ \text { withPersonal } & & & & \\ \text { problems } & & & & \end{array}$

The table 3 below shows the results of a comparative analysis of breach of individual Psychological contract items for male employees and female employees.

Question I had a mean of 24 of the total variance on how important is promotion is attached to the employer obligations.

Question II used a mean of 24 of the total variance on how important is high pay is attached to the employer obligations.

Question III accounted for a mean of 24 of the total variance on how important is training is attached to the employer obligations.

Question IV, a mean of 24 of the total variance on how important is job security is attached to the employer obligations.

Question V used a mean of 24 of the total variance on how important career development is attached to the employer obligations.

Question VI had a mean of 24 of the total variance on how important is Personnel support is attached to the employer obligations.

A further comparison is made between Married and Unmarried employees, thus giving rise to 4 mutually exclusive groups: married males, unmarried males, married females and unmarried females. There is a higher level of Psychological Contract breach in the case of Males, as far as expectations related to Promotions, High Pay, Pay based on performance and Career

Table 3

Comparative analysis of breaching of individual Psychological contract items

\begin{tabular}{lllll}
\hline & Male & Female & Mean & Std Dev \\
\hline Whether & 78 & 72 & .2612 & 2.6 \\
support with & & & & \\
Personal \\
problems is \\
breached
\end{tabular}




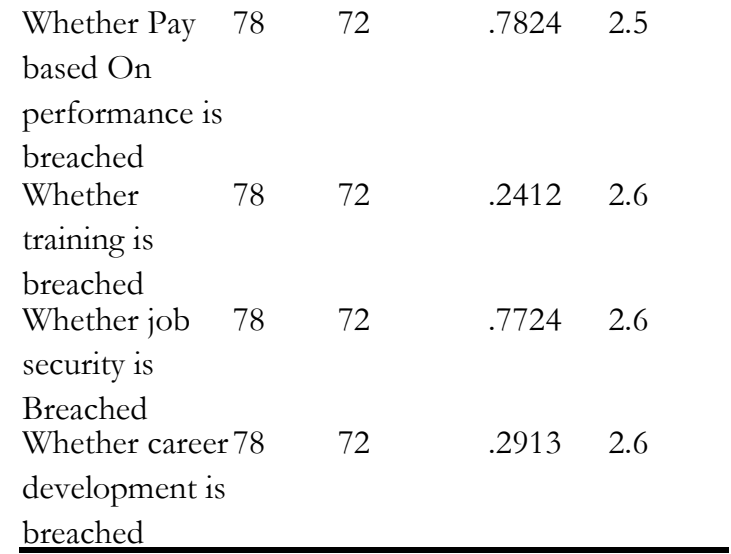

Regression analysis (using SPSS software) with 'Intention to quit' as the dependent variable and 'Psychological Contract Breach as the independent variable yielded the following results:

Table 4

Model Summary

\begin{tabular}{|c|c|c|c|c|}
\hline Model & $\mathrm{R}$ & $\begin{array}{l}\mathrm{R} \\
\text { Square }\end{array}$ & $\begin{array}{l}\text { Adjusted R } \\
\text { Square }\end{array}$ & $\begin{array}{l}\text { Std. Error of } \\
\text { the Estimate }\end{array}$ \\
\hline 1 & $0.790(\mathrm{a})$ & 0.620 & 0.541 & 0.85945 \\
\hline
\end{tabular}

Table 5

ANOVA b

\begin{tabular}{lrll}
\hline Model & $\begin{array}{l}\text { Sum of } \\
\text { Squares }\end{array}$ & $\begin{array}{l}\text { Mean } \\
\text { Square }\end{array}$ & F Sig. \\
\hline Regression19.3695 & 3 & $6.45657 .4740 .000(\mathrm{a})$
\end{tabular}

Residual $\quad 11.2305 \quad 26 \quad 0.864$

Total $\quad 30.6000 \quad 29$

Table 6

Coefficients

\begin{tabular}{|c|c|c|c|c|c|}
\hline \multirow[t]{2}{*}{ Model } & \multicolumn{2}{|c|}{$\begin{array}{l}\text { Un-standardized } \\
\text { Coefficients }\end{array}$} & $\begin{array}{l}\text { Standardize } \\
\text { d } \\
\text { Coefficients }\end{array}$ & \multirow[t]{2}{*}{$\mathrm{t}$} & \multirow[t]{2}{*}{ Sig. } \\
\hline & B & \multicolumn{2}{|c|}{ Std. Error Beta } & & \\
\hline$\overline{\text { (Constant) }}$ & 0.223 & 0.769 & & 0.290 & 0.004 \\
\hline $\begin{array}{l}\text { Job } \\
\text { security }\end{array}$ & 0.867 & 0.148 & 0.757 & 5.869 & 0.000 \\
\hline High Pay & 0.115 & 0.123 & 0.935 & 0.115 & 0.123 \\
\hline $\begin{array}{l}\text { Career } \\
\text { developme } \\
\text { nt }\end{array}$ & 0.095 & 0.138 & 0.092 & 0.668 & 0.007 \\
\hline
\end{tabular}

The null hypothesis $\mathrm{H} 0$ is rejected. Thus, there is a significant relationship between Psychological contract breach and Employees performance. The R square $(0.541)$ which is the explained variance shows that $62 \%$ of the variance in Intention to Quit has been significantly explained by the independent variable, Psychological Contract Breach.

The empirical results here support that psychological contract breaches have a negative impact on employee's organizational behaviour. Employees' performance reflects the subjective probability that an individual will leave his or her organization within a certain period of time. Intention to quit can serve as an indicator of the extent of one's psychological attachment to the organization. As opposed to actual turnover, the employees' performance variable is not dichotomous. In addition, it is less constrained by exogenous factors (such as availability of an alternative job) and thus more accurately reflects one's attitude toward the organization. Intention to quit is a common response to negative events with work (Lum, Kervin, Clark, Reid, \& Sirola, 2011). Thus, psychological contract breach, as a negative effect for employees, can increase their tendency to leave.

The current study focused on the moderating role of social exchanges in the relation between psychological contract breach and work performance. First, the study proposed that psychological contract breach would be negatively related to work performance. The study found support for a negative relationship with both job performance and organizational citizenship behaviors, supporting previous research on the effects of psychological contract breach (CoyleShapiro, 2012; Turnley et al., 2011; Zhao et al., 2007).

This study found strong support for the intensifying-hypothesis. An overall five out of six possible interactions were significant, and further analyses showed that the relations of contract breach with work performance were negative for employees with high social exchange (Career Development, Pay Base, and job security ), whereas the same relationship was not significant for employees with low social exchanges. Visual inspection showed that work performance was lower for employees with low social exchanges, regardless of the level of psychological contract breach, whereas performance was higher among high social exchange employees, and it decreased for high levels of psychological contract breach.

Contrary to expectations the study found that job security did not moderate the relation between psychological contract breach and OCBs. It might be 
that whereas Career Development and Pay Base refer to a straightforward exchange relationship between the employee and the organization, job security refers to a more complex relation between the employee and the organization (Atkinson and Butcher, 2011; Dirks and Ferrin, 2012). More specifically, job security may be based on either taskbased competence or personal motives (Atkinson \& Butcher, 2011). Atkinson and Butcher argue that when employees' job security in their organization is only based on fulfillment of basic tasks of the organization, employees may have low emotional attachment to the organization.

However, if the trusted party (the organization) may contribute to personal motives of the employee, their emotional attachment will be higher and more is at stake in their relationship. An explanation of the current findings might be that employees' job security in the organization was primarily based on task competence, such that psychological contract breach was not related to a stronger decrease of OCBs for those with high pay. If pay is primarily based on fulfillment of personal motives, pay would be a more important component of the relationship between the employee and the organization. Therefore, contract breach would be a more profound damage of this job security -based relationship, leading to more severe effects on OCBs. Future research may shed more light on these different bases of job security and should investigate the nature of job security in the organization as well as the nature of psychological contract breach.

\section{Conclusion}

The new generation private sector banks and foreign banks offer lucrative job opportunities in terms of pay, perks and working environment to their employees. The consequence of this is that public sector and old generation private sector employees get attracted to joining these firms and may contemplate quitting or may actually quit these banks (Dagar, 2007). Employees of Public sector and old generation private sector banks opting for these employment opportunities are showing their discomfort and dissatisfaction with their current job despite job security. Therefore, attracting and retaining talent is another emerging concern for the public sector banks and old generation private sector.

The results here support the idea that the Psychological contract breach has a pervasive positive impact on employees' intention to quit behaviour. Thus the negative consequences of psychological contract breach are intended to go beyond hurting individual employees' feelings: but the psychological contract breach may lead to damaging the organization through losing its talented employees. These findings support the traditional wisdom that the psychological contract is an important concept in understanding the employment relationships.

The study showed that there are two theoretical meaningful interactions between psychological contracts and social exchanges. The results showed strong support for the intensifying-hypothesis, which stated that especially employees with high social exchanges feel betrayed by their organizations when their psychological contracts have been broken. To reciprocate the contract breach, they diminish their efforts, thus negatively impacting job performance and OCBs. The results reveal important boundary conditions in the relations between contract breach and work performance.

\section{References}

Aguinis, H. (2012), "Estimation of interaction effects in organizational studies", Organizational Research Methods, Vol. 5 No. 3, pp. 207-11.

Aguinis, H., Beaty, J.C., Boik, R.J. and Pierce, C.A. (2010), "Effect size and power in assessing moderating effects in categorical variables using multiple regression: a 30year review", Journal of Applied Psychology, Vol. 90 No. 1, pp. 94-107.

Coyle-Shapiro, J.A.M. and Conway, N. (2009),

"The employment relationship through the lens of social exchange", in Coyle-Shapiro, J.A.M., Shore, L.M., Taylor, M.S. and Tetrick, L.E. (Eds), The Employment Relationship. Examining Psychological and Contextual, Oxford University Press, Oxford, UK, pp. 5-28.

Dulac, T., Coyle-Shapiro, J.A.M., Henderson, D.J. and Wayne, S.J. (2008), "Not all responses to breach are the same: the interconnection of social exchange and psychological contract processes in organizations", Academy of Management Journal, Vol. 51 No. 6, pp. 1079- 98.

Dunn, J.R. and Schweitzer, M.E. (2010), “Feeling and believing: the influence of emotion andjob security", Journal of Personality and Social Psychology, Vol. 88 No. 5, pp. 73648.

Eisenberger, R., Huntington, R., Hutchinson, S. 
and Sowa, D. (1986), "Perceived organizational support", Journal of Applied Psychology, Vol. 71 No. 3, pp. 500-7.

(2009), "Work value congruence and intrinsic career success: the compensatory roles of leader-member exchange and perceived organizational support", Personnel Psychology, Vol. 57, pp. 305-32.

Guest, D.E. (2009), “The psychology of the Employment relationship: an analysis based on the psychological contract", Applied Psychology: An International Review, Vol. 53 No. 4, pp. 541-55.

Johnson, J.L. and O'Leary-Kelly, A.M. (2011), "The effects of psychological contract breach and organizational cynicism: not all social exchange breach are created equal", Journal of Organizational Behavior, Vol. 24, pp. 627-47.

Kickul, J. and Lester, S.W. (2011), "Broken promises: equity sensitivity as a moderator between psychological contract breach and employee attitudes and behavior", Journal of Business and Psychology, Vol. 16 No. 2, pp. 191-218.

Lavelle, J.J., Rupp, D.E. and Brockner, J. (2007), "Taking a multi foci approach to the study of justice, social exchange, and citizenship behavior: the target similarity model", Journal of Management, Vol. 33 No. 6, pp. 841-66.

Robinson, S.L. and Morrison, E.W. (2009), "Psychological contracts and OCB: the effects of unfulfilled obligations on civic virtue behavior", Journal of Organizational Behavior, Vol. 16 No. 3, pp. 289-98.

Rousseau, D.M. (2009), Psychological Contracts in Organizations. Understanding Written and Unwritten Agreements, Sage, Thousand Oaks, CA.
Shore, L.M., Tetrick, L.E., Taylor, M.S., CoyleShapiro, J.A.M., Liden, R.C. and Parks, J.M. (2009),"The employee-organization relationship: a timely concept in a period of transition", in Martocchio, J.J. (Ed.), Research in Personnel and Human Resources Management, Elsevier, Oxford, pp. 291-370.

Suazo, M.M., Martı'nez, P.G. and Sandoval, R. (2009), "Creating psychological and legal contracts through human resource practices: a signaling theory perspective", Human Resource Management Review, Vol. 19 No. 2, pp. 154-66.

Tekleab, A.G., Takeuchi, R. and Taylor, M.S.

(2010), "Extending the chain of relationships among organizational justice, social exchange, and employee reactions: the role of contract breach", Academy of Management Journal, Vol. 48 No. 1, pp. 146-57.

Turnley, W.H., Bolino, M.C., Lester, S.W. and Bloodgood, J.M. (2011), "The impact of psychological contract fulfillment on the performance of in-role and organizational citizenship behaviors", Journal of Management, Vol. 29 No. 2, pp. 187-206.

Zhang, A.Y., Tsui, A.S., Song, L.J., Li, C. and Jia, A.L. (2008), "How do I job security thee? The employee-organization relationship, supervisory support, and middle manager job security in the organization", Human Resource Management, Vol. 47 No. 1, pp. 111-32.

Zhao, H., Wayne, S.J., Glibkowski, B.C. and Bravo, J. (2007), "The impact of psychological contract breach on workrelated outcomes: a meta-analysis", Personnel Psychology, Vol. 60,pp. 64 